\title{
INTEREST COVERAGE RATIOS (ICRs) AND FINANCIAL SUSTAINABILITY: APPLICATION TO FIRMS WITH BOVINE DAIRY LIVESTOCK
}

\author{
Giuseppe Bonazzi and Mattia Iotti \\ Department of Civil Engineering, Environment, \\ Territory and Architecture (DICATeA), University of Parma, Parma, Italy
}

Received 2014-09-15; Revised 2014-09-25; Accepted 2014-09-29

\begin{abstract}
Agricultural firms with bovine dairy livestock are characterized by high investments in capital equipment and this is determined by the biological cycle of production, which requires large investments in land, facilities and bovine herd. These large investments require funding from equity capital or debt capital, which generates financial costs. Therefore, it is necessary to assess not only the profitability of firms in the sector but also the financial sustainability of the business cycle, applying appropriate indexes. To analyze this issue, the article has developed an approach to the verification of the financial sustainability of debt, out of a sample of dairy companies in Italy, putting in comparison Interest Coverage Ratios (ICRs) calculated using different approaches. In the article, we propose a financial approach to calculate the ICRs and verify the correlation and diversity, where statistically significant, of ICRs calculated with the Financial (FICRs) and the Economic (EICRs) approaches. The research shows that the sample firms have difficulty in generating cash flow and this difficulty is highlighted by traditional profitability analysis. Likewise, EICRs traditionally applied by banks are statistically different, even if correlated, with respect to the FICRs proposed in the article. The results of the research suggest that firms in the sector must pay particular attention to the financial sustainability of operations, in particular in dealing with the banks for the financing of debts. Similarly, banks should put in place systems analysis that are more effective than those currently used to assess the agricultural firms. The suggested approach could be applied even to other sectors' agrifood system, particularly if capital intensive; at the same time, the approach could be useful also if applied to agricultural cooperatives, even in developing countries that often suffer by financial constraints.
\end{abstract}

Keywords:Interest Coverage Ratios (ICRs), Bovine Dairy Livestock, Financial Sustainability, ParmigianoReggiano PDO Cheese

\section{INTRODUCTION}

Agricultural firms with bovine dairy livestock are an important part of the agricultural sector in Italy, particularly in the northern regions, including the EmiliaRomagna and Lombardia regions. These companies are active in the production of milk and often in the production of milk that is used for processing into cheese of Protected Designation of Origin (PDO). Among these cheeses, Grana Padano and Parmigiano-Reggiano cheeses are of greater production; these cheeses are sold in Italy and in many countries around the world, thus ensuring an important market outlet for Italian milk production, which occurs in farms with bovine dairy cattle. These firms, however, have difficulties in varied order. First, companies do not control the market price of the finished product. In fact, the manufacturing market is highly fragmented and the production is sold to the final Engineering, Environment, Territory and Architecture (DICATeA), University of Parma, Parma, Italy
AJABS 
consumer through commercial intermediaries or through retail chains. Rare are the cases where farms sell directly a part of their production on the market. These companies also have difficulty in controlling production costs; in fact, the relevant cost of supply of raw materials for animal feed and the variability of the market price are a frequent problem for companies in the sector and represent a critical element of the management. In this general context of operational problems, we must also consider that the companies in the sector are often characterized by high capital intensity. These investments are determined by the biological cycle of production, which requires large investments in land, facilities and bovine cattle. Large investments require funding with equity capital or debt capital, which generates financial costs. Debt can be implicitly onerous, as in the case of trade payables, or explicitly onerous, as in the case of bank debt. The evaluation of convenience, therefore, concern the quantification of the performance of equity capital, while sustainability is the quantification of the payment of the cost of debt and the repayment of debt. Firms' management must then assess the performance of equity capital injected and jointly evaluate the Cash Flows (CFs) generated from operations to quantify whether these are sufficient to ensure the sustainability of the business cycle, in terms of payment of cost of debt. In firms with agricultural bovine livestock dairy, this assessment is relevant because of the time lag that exists between the business cycle and the financial cycle, which can lead to decisions that are strategically wrong, with the risk of default for companies. Many firms in the sector, for example, those producing milk for Grana Padano and ParmigianoReggiano cheeses, receive payment for the milk even more than 12 months after the sale or transfer to the dairy cooperatives. This often generates financial problems, particularly if firms operate in cooperative form (Chaddad et al., 2005; Limsombunchai et al., 2005; Bonazzi and Iotti, 2014).

Only in the regions of Northern Italy has the number of farms with bovine dairy livestock in fact decreased from 35,420 in 2000 to 17,695 in 2010 , the last official census. To analyze the causes of the decrease in the firms' number, a fundamental approach is to quantify the cost-effectiveness of management and on this issue, many studies are interested in the typical production in Italy (Tudisca et al., 2013; Sgroi et al., 2014; Tudisca et al., 2014a; 2014b; Iotti and Bonazzi, 2014a). Several studies have demonstrated that the Economic Interest Coverage Ratios approach (EICRs) and the Financial Interest Coverage Ratios approach (FICRs) may give different results and firms with positive profits may have difficulties in the financial cycle (Grenberg et al., 1986; Kwon, 1989; Dechow, 1994; Dechow and Dichev, 2002; Russel, 2009; Iotti and Bonazzi, 2014b; 2014c). In particular, this situation occurs in Small-and Mediumsized Enterprises (SMEs) compared with large companies; SMEs, in fact, often have difficulties in gaining source of capital (Glancy, 1998; Kieschnick et al., 2008). Again, SMEs have limited access to capital market risk (stock market, venture capital, private equity, etc.) and debt capital (bank loans, structured finance, syndicated loans) as highlighted by several studies (Grablowsky, 1984; Dunn and Cheatham, 1999; Peel and Wilson, 1996; Molina and Preeve, 2009). To analyze this issue in the article, an approach has been developed to verify the financial sustainability of debt, out of a sample of bovine dairy livestock in Italy, putting in comparison Interest Coverage Ratios (ICRs) calculated using different approaches. The article proposes an FICR to calculate ICRs and verify the correlation and diversity, where statistically significant, between the traditional EICRs and the FICRs. The FICRs approach has already been developed for other sectors (Iotti and Bonazzi, 2012) but has never been applied in the sector of bovine dairy livestock. The ratios applied in the research allow a more accurate assessment of corporate sustainability in the method of calculation and this method may have utility, first, for the business owner to properly assess in advance the sustainability of the management cycle and second, to the institutions' credit so that they would be able to assess, with greater accuracy, the creditworthiness of companies. At the end, the suggested method could be properly applied even by policy makers who operate with direct (loans to income and/or capital) or indirect (mutual guarantee) aid policies in favor of firms for which the ability to use public funds as received is evaluated with correctness, thus limiting the risk of inefficient use of collective resources (Bonazzi et al., 2012).

\section{MATERIALS AND METHODS}

Several studies have aimed to evaluate the ability of the company to pay the cost of debt and repay the debt contract (Grenberg et al., 1986; Krishnan and Largay, 2000; Dothan, 2006; Trejo-Pech et al., 2006; Kieschnick et al., 2008; Demerjian, 2011). In fact, the firm must be able not only to reward the equity capital but also to have financial sustainability. This ability is in generating sufficient $\mathrm{CF}$ to pay the cost of the debt and repay the debt. To perform this analysis, ICRs are frequently applied. A traditional approach, which is widely used by banks, uses ICRs, calculated according to 
the EICRs, that is, using profit margins. These margins are usually Earnings Before Interest, Taxes, Depreciation and Amortization (EBITDA) and Earnings Before Interest and Taxes (EBIT). However, EBITDA and EBIT do not directly express CF available to serve financial debt, but they do approximate it. We define EBITDA/EBIT-based ICRs as EICRs. In the article, we even apply a CF-based approach, in which ICRs are calculated with FICRs, then directly apply CF measures, such as $\mathrm{CF}$, Operating $\mathrm{CF}$ (OCF) and Unlevered Free $\mathrm{CF}$ (UFCF). We define the CF-OCF-UFCF based ICRs as FICRs and would verify if EICRs are correlated with FICRs, even if EICRs and FICRs are statistically different, applying these ICRs to a firms' sample in the sector of dairy livestock.

The EICRs quantify in fact profit, applying the value management approach, when the financial management approach considers the result in terms of cash inflow and outflow, as streams of cash (Kwon, 1989; Copeland et al., 2000). The EICRs consider the positive and negative voices of income to calculate profit. We can express the EICRs, defining the value of production for a generic time $t$ in the income statement, as:

$$
\begin{aligned}
& V P_{t}-\left(M_{t}+S_{t}+R_{t}+L_{t}+O_{t}\right)=E_{B I T D A_{t}} \\
& E B I T D A_{t}-\left(D_{t}+A_{t}\right)=E B I T_{t}
\end{aligned}
$$

In Equation 1, VP and operative monetary costs are raw material costs $\left(M_{t}\right)$, costs for services $\left(S_{t}\right)$, rent and leasing costs $\left(R_{t}\right)$, labor costs $\left(L_{t}\right)$ and other operative costs $\left(O_{t}\right)$. Nonmonetary operating costs as amortization of tangible and intangible fixed assets $\left(D_{t}\right)$ and depreciation and risk provisions $\left(A_{t}\right)$ are then considered to quantify EBIT. EBITDA approximates the creation of liquidity, not considering nonmonetary costs $\left(D_{t}+A_{t}\right)$; again, EBIT is the operating income margin that expresses the intermediate operative income margin. EICRs quantify intermediate income margins, while FICRs quantify available CF. FICRs could be summarized by applying the CF statement (Wallace et al., 1997; Krolick, 1998; Penman, 2004). The most important financial margins are as follows:

$$
\begin{aligned}
& E B I T_{t}+\left(D_{t}+A_{t}\right)=C F_{t} \\
& C F_{t}-\left(N W C_{t}-N W C_{t-1}\right)=O C F_{t} \\
& O C F_{t}-\left(F A_{t}-F A_{t-1}\right)-\left(D_{t}+A_{t}\right)=U F C F_{t}
\end{aligned}
$$

In Equation 2, which considers EBIT as the first source of cash, NWC is net working capital and FA is investment in fixed asset. It is to be considered that $\Delta^{+} N W C_{t, t-1}=>\Delta^{-} O C F_{t, t-1}$, given that an increase in net working capital, which increases income, implies an absorption of liquidity, reducing operating $\mathrm{CF}$ and vice versa in the case of negative variation $\left(\Delta^{-} N W C_{t, t-1}=>\Delta^{+} O C F_{t, t-1}\right)$. Again, an increase in inventories value $\left(\Delta^{+} I_{t, t-1}\right)$, which increases income, implies a reduction in the operating $\mathrm{CF}\left(\Delta^{+} I_{t, t-}\right.$ $\left.{ }_{1}=>\Delta^{-} O C F_{t, t-1}\right)$ and vice versa in the case of negative variation $\left(\Delta^{-} I_{t, t-1}=>\Delta^{+} O C F_{t, t-1}\right)$. Given $\mathrm{OCF}_{\mathrm{t}}$, the liquidity absorption due to the fixed asset investment has an effect on $U F C F_{t}$, given that $\left[\left(F A_{t}-F A_{t-1}\right)-\left(D_{t}+A_{t}\right)\right]>0$ $=>\Delta^{-} U F C F_{t, t-1}$ and vice versa. $\mathrm{UFCF}_{\mathrm{t}}$ is therefore the CF available, given the investments in fixed assets, at time $t$, to remunerate the financial debt and equity capital. Information based on a $\mathrm{CF}$ approach has its practical applications considering the limits of a traditional accounting system, which is based on the principles of historical cost and accrual basis value analysis. The importance of quantifying operating $\mathrm{CFs}$, in comparison with accounting values, is exposed by several studies that consider the limits of a traditional accounting system, based on the historical cost principles, applying an accrual basis value analysis (Finger, 1994; Wang and Eichenseher, 1998; Charitou and Panagitodes, 1999; Hussain and Al-Attar, 2003). EBITDA and EBIT often applied even in cover ratio covenants (Dothan, 2006; Gray et al., 2006) do not directly express the liquidity generated by firm management. EICRs traditionally applied by banks are as follows Equation 3:

$$
\begin{aligned}
& E I C R 1=E B I T D A_{t} / I C_{t} \\
& E I C R 2=E B I T_{t} / I C_{t}
\end{aligned}
$$

EICR1 expresses the firm's capacity to pay the cost of debt in a given time $t$, using the EBITDA margin (Dothan, 2006); EICR2 applies a more prudential approach (Goldstein et al., 2001) because $\left(D_{t}+A_{t}\right) \geq 0$ $\Rightarrow$ EBITDA $_{\mathrm{t}} \geq \mathrm{EBIT}_{\mathrm{t}} \Rightarrow \mathrm{EICR} 1 \geq \mathrm{EICR}^{2}$. EICRs are applied to evaluate the ability of firms to pay for the cost of debt and therefore are fundamental indices for the assessment of creditworthiness in the valuation of bank credit (Dichev and Skinner, 2002; Bahiraie et al., 2009; Demerjian, 2011). If IC $=0$, the calculation of the EICRs loses significance from the absence of cost of debt. EICRs present in the numerator are characterized by profit margin as EBITDA and EBIT, which are measures of the sustainability of the business cycle based on income, which is often used as a variable to proxy CF as in (Healy, 1985; Sloan, 1996). These researchers have been considered the standard in the accounting literature until the introduction of a more complete model by 
Richardson (2005), whose work is considered the basis for the definition of the relationship between accounting information and CFs. Then the evaluation of the ability of firms to access credit and to serve a debt contract on the basis of profit margins can lead to biased results, in which firms take strategic decisions that overestimate or underestimate their ability to cope with the debt contract, as what frequently happens in practice and in banking for access to credit. To overcome these limitations of the EICRs, in the research, we suggest and apply the following ratios Equation 4:

$$
\begin{aligned}
& \mathrm{FICR} 1=\mathrm{CF}_{\mathrm{t}} / \mathrm{IC}_{\mathrm{t}} \\
& \mathrm{FICR} 2=\mathrm{OCF}_{\mathrm{t}} / \mathrm{IC}_{\mathrm{t}} \\
& \text { FICR3 }=\mathrm{UFCF}_{\mathrm{t}} / \mathrm{IC}_{\mathrm{t}}
\end{aligned}
$$

FICR1 expresses the ability of the firm to pay the cost of the debt, in a generic period t, with $\mathrm{CF}$, while FICR2 and FICR3 express the same concept but apply more precise financial margins as OCF and UFCF, respectively.

\section{RESULTS}

The analysis was conducted on a sample of 50 companies with agricultural bovine dairy livestock; firms' samples are active in the form of a corporation and work in Italy, in the regions of Lombardia (Province of Mantova, Cremona, Lodi) and Emilia-Romagna (the provinces of Modena, Reggio Emilia and Parma). Data were randomly drawn from the annual accounts in the "computerized analysis of Italian firms" AIDA database, considering base year 2008; the dates extraction covers the five-year period from 2008 to 2012 and uses the annual accounts filed by companies' Register each year.

We consider a total of 226 firm-year observations and 24 observations were not used in the calculations as they were missing in the database. The data analysis was performed using the SPSS statistical package, issue 19. The random extraction from the database of the 50 firms in the sample takes into account these extraction parameters: (1) The extracted firms are limited company as defined in the Italian Civil Code and in the sample, cooperative firms are not included; (2) the extracted firms are classified as agrifood firms in accordance with the classification of the National Institute of Statistics of Italy (ISTAT).

This article develops the analysis as follows: (a) We calculate the average annual account data (income statement and balance sheet) of the sample firms; (b) we reclassify the annual accounts of the firms, calculating the averages of the income statement and the balance sheet in the form reclassified; (c) we calculate EICRs and FICRs; (d) we test whether there are statistically significant correlations in the values of EICRs and FICRs; (f) we test whether there are statistically significant differences in the values of EICRs and FICRs. Mean (M) and median (ME) values of ICRs are, respectively, as follows: EICR1, $\mathrm{M}$ is 3.22 and $\mathrm{ME}$ is 3.02; EICR2, $\mathrm{M}$ is 2.11 and $\mathrm{ME}$ is 2.12; FICR1, $\mathrm{M}$ is 3.54 and $\mathrm{ME}$ is 4.15; FICR2, $\mathrm{M}$ is 2.08 and ME is 1.91 ; FICR3, $\mathrm{M}$ is 1.27 and $\mathrm{ME}$ is 1.22 . We would remember that ICR $>1$ to ensure firms' capacity to pay cost of debt (IC).

In Table 1, we calculate the correlations between the ICRs (EICRs and FICRs), applying a parametric approach (Pearson correlation). The data show that ICRs are strongly correlated with each other, with a 0.01 level of significance, (two-tailed) for three correlations (EICR2/FICR1, EICR2/FICR2, EICR2/FICR3) and with a 0.05 level of significance (two-tailed) for three correlations (EICR1/EICR2, EICR1/FICR1, FICR2/EICR3). We do not detect correlations between EICR1/FICR2, EICR1/FICR3, FICR1/FICR2 and FICR1/FICR3. KolmogorovSmirnov D statistic on normality of distr ibution showed that all distributions of the ICRs follow the normal, so it was not considered necessary to apply a nonparametric approach, such as Spearman's rho test.

In Table 2 analyzed if the values of the ICRs are different in terms of statistical significance, both applying the EICRs and the FICRs approaches. This information is necessary both for theoretical purposes to determine if the different ratios could be used as substitutes for one another, after quantifying correlations; this information is also relevant for firms' managers and banks, to know whether they are using the correct ratios to assess the sustainability of the business cycle in relation to cost of debt. In the article, we propose 10 comparisons for ratio pairs, comparing all the ICRs exposed in the "Material and Methods" section. The aim of the comparison is to evaluate if ratios are equal or are statistically different. The data show that the ICRs are different from one another with a 0.01 level of significance (two-tailed) for four pairs of ICRs (couples 3, 4, 8 and 9); significance level is 0.05 (twotailed) for one pair of ICRs (couple 2). Data analysis did not express statistical difference for the means in couples 1, 5, 6, 7 and 10. Kolmogorov-Smirnov D statistic on normality of distribution showed that all distributions of the ICRs follow the normal, so it was not considered necessary to apply a nonparametric approach, such as the Wilcoxon approach. 
Table 1. Correlation between ICRs (EICRs and FICRs)-parametric approach (Corr. Pearson)

\begin{tabular}{|c|c|c|c|c|c|c|}
\hline \multicolumn{2}{|c|}{ ICRS (EICRs and FICRs) } & \multirow{3}{*}{$\begin{array}{l}\text { EICR } 1_{\text {EBITDA/IC }} \\
1\end{array}$} & \multirow[t]{3}{*}{ EICR $2_{\text {EBIT/IC }}$} & \multirow[t]{3}{*}{ FICR $1_{\mathrm{CF} / \mathrm{IC}}$} & \multirow[t]{3}{*}{ FICR $2_{\text {OCF/IC }}$} & \multirow[t]{2}{*}{ FICR $3_{\text {UFCF/IC }}$} \\
\hline$\overline{\text { EICR1 }} 1_{\text {EBITDA/IC }}$ & Corr. Pearson & & & & & \\
\hline & Sig. (2-tailed) N. 226 & & & & & \\
\hline \multirow[t]{2}{*}{ EICR2 2 EBIT/IC } & Corr. Pearson & $0.177 *$ & 1 & & & \\
\hline & Sig. (2-tailed) N. 226 & 0.012 & & & & \\
\hline \multirow[t]{2}{*}{ FICR $1_{\mathrm{CF} / \mathrm{IC}}$} & Corr. Pearson & $0.135 *$ & $0.280^{* * *}$ & 1.000 & & \\
\hline & Sig. (2-tailed) N. 226 & 0.047 & 0 & & & \\
\hline \multirow[t]{2}{*}{ FICR $2_{\text {OCF/IC }}$} & Corr. Pearson & 0.025 & $0.248^{* *}$ & 0.078 & 1 & \\
\hline & Sig. (2-tailed) N. 226 & 0.455 & 0 & 0.240 & & \\
\hline \multirow[t]{2}{*}{ FICR $3_{\text {UFCF/IC }}$} & Corr. Pearson & 0.005 & $0.285^{* *}$ & 0.090 & $0.135^{*}$ & 1 \\
\hline & Sig. (2-tailed) N. 226 & 0.966 & 0 & 0.247 & 0.044 & \\
\hline
\end{tabular}

**.Value significant at the 0.01 level (2-tailed); *.Value significant at the 0.05 level (2-tailed); Source: Our processing of directly collected data

Table 2. Comparison of ICRs-parametric approach for paired samples (t-Student)

\begin{tabular}{|c|c|c|c|c|c|c|c|}
\hline \multirow[b]{2}{*}{ Couples of value } & & \multicolumn{6}{|c|}{ Values and statistics } \\
\hline & & Mean & Standard Dev. & Mean standard error & $\mathrm{t}$ & df & Sig. (2-tailed) \\
\hline Couple 1 & EICR1-EICR2 & 3.102 & 7.524 & 3.225 & 1.401 & 225 & 0.121 \\
\hline Couple 2 & EICR1-FICR1 & 2.233 & 8.325 & 2.158 & 2.344 & 225 & $0.021 *$ \\
\hline Couple 3 & EICR1-FICR2 & 7.094 & 8.480 & 1.855 & 4.523 & 225 & $0.000 * *$ \\
\hline Couple 4 & EICR1-FICR3 & 1.128 & 3.843 & 3.589 & 3.440 & 225 & $0.000 * *$ \\
\hline Couple 5 & EICR2-FICR1 & 4.155 & 1.247 & 3.392 & 0.980 & 225 & 0.322 \\
\hline Couple 6 & EICR2-FICR2 & 2.135 & 11.234 & 5.194 & 1.121 & 225 & 0.156 \\
\hline Couple 7 & EICR2-FICR3 & 9.185 & 0.034 & 6.348 & 0.848 & 225 & 0.410 \\
\hline Couple 8 & FICR1-FICR2 & 0.890 & 2.665 & 3.164 & 4.860 & 225 & $0.000 * *$ \\
\hline Couple 9 & FICR1-FICR3 & 1.774 & 5.776 & 6.101 & 4.331 & 225 & $0.000 * *$ \\
\hline Couple 10 & FICR2-FICR3 & 1.032 & 6.977 & 6.999 & 1.601 & 225 & 0.199 \\
\hline
\end{tabular}

**. Value significant at the 0.01 level (2-tailed); *.Value significant at the 0.05 level (2-tailed); Source: Our processing of directly collected data

\section{DISCUSSION}

The companies with agricultural bovine dairy livestock are capital-intensive firms. The milk product is often processed into cheese, increasing the duration of the financial cycle, because of the aging period. Since the change in inventories and sales not yet collected affect as positive components of the production value and profit of the companies, it could be a misalignment between profit and $\mathrm{CF}$ in firms in the sector; this misalignment could cause situations in which companies, even with positive profits, are not able to support the financial cycle. During our research, we have found that firms in the sample use mainly the following forms of financing, in addition to equity capital: For the financing of investments in property, plant and equipment, as fixed-asset investments, companies prefer medium/long-term bank loans, articulated generally in the technical form of the mortgage usually secured on real estate values and, less frequently, as an unsecured claim, with shorter amortization and any collateral (usually on securities), even with a guarantee of credit guarantee. In the case of medium-/long-term loans, firms have the contractual obligation to repay debt based on an amortization schedule of the debt plus interest expense (so-called debt service), whereas in the case of shortterm loans, firms pay the cost of debt and then proceed to the payment of the principal of the loan through monetization of supplies of goods acquired through cash inflow of trade receivables. The ICRs calculation could be applied properly to assess firms' capacity to ensure financial cost payment. So knowing if there is a correlation between ICRs calculated according to EICRs and FICRs would allow managers of enterprises to use the right ratios to assess the sustainability of the business cycle in the debt service. Similarly, we require to know if EICRs and FICRs are statistically different; if, in fact, EICRs and FICRs are equal, the ratios can be used as substitutes for one another, because if the indices are different from each other, it is necessary to identify which indexes are more accurate and apply these ratios to assess the sustainability of the management. 
The analysis of the sample data has allowed us to make some important reflections, which can be developed in further research. First, research has shown that EICR1 is poorly correlated with other ICRs $(0.05$ correlation level, two-tailed, with EICR2 and FICR1), whereas it is not correlated with FICR2 and FICR3, which is the most important ICRs and judged to be more reliable. It is therefore clear that EICR1, considered very relevant in the covenants of the banks for the formation of the term sheet, is really an index that is not reliable. EICR2 presents itself as a reliable index, is strongly correlated with all FICRs and then is correctly applied in the determination of free $\mathrm{CF}$. The research suggests that FICR1, even if related to EICRs, is not related to the other FICRs; this conclusion requires an analysis, as CF has been for many years considered a reliable indicator of cash generation of the firms; the outcome of our research seems to indicate that $\mathrm{CF}$ is, however, in the bovine dairy livestock sector, an imperfect indicator of financial sustainability of management cycle.

The analysis also shows that there are statistically significant differences between the values of ratios; in fact, EICR1 is significantly different from FICR2 and IFRC3 and similarly, FICR1 is significantly different from FICR2 and IFRC3. It is therefore clear that EBITDA (EICR1) and CF (FICR1) cannot be used for approximating the other economic and financial margins, which are based on the calculation of the ICRs. In addition, EBITDA and CF are statistically higher than EBIT, OCF and UFCF. If the firms' managers in the sample will apply EICR1 and FICR1 to assess the financial sustainability of operations, by calculation of the ICRs, they overestimate this capacity, taking decisions based on inaccurate values.

The analysis thus shows that the ratios of sustainability management cycle and debt service, traditionally used by businesses and banks, in particular EICR1 and FICR1, do not properly express sustainability. Among the traditional indices, it seems, however, that EICR2 is more reliable than EICR1, even if preferable ratios are FICR2 and FICR3.

\section{CONCLUSION}

The analysis in this article, applied to a sample of agricultural firms operating in the northern part of Italy, considers firms producing milk, mainly for processing aged cheese (Grana Padano and Parmigiano-Reggiano PDO cheeses). These companies have, on average, invested heavily, financing investment with financial debt. The research wants to test the ability to pay the cost of debt by calculating the ICRs; research has provided a calculation approach with a traditional economic (applying EICRs) and a financial approach (applying FICRs). The two approaches have been applied on a sample of 226 observations (series of 5 years, 50 enterprises, 24 missing data), by analysis of correlation and analysis of significance of the difference between average values. In general, the analysis showed that the sample firms have difficulty paying the cost of debt. In fact, on a sample of 226 observations, EICR1>1 in 207 cases, EICR2 $>1$ in 178 cases, FCR1>1 in 212 cases, FCR2 $>1$ in 175 cases and FCR2>1 in 122 cases. This confirms that firms with bovine dairy livestock have difficulty coping with the cost of financial indebtedness. This difficulty emerges, however, more clearly by applying calculation of FICRs; however, among EICRs, EICR2 appears to be preferable to EICR1. The analysis also shows that although they are characterized by different values, a correlation between ICRs calculated with EICRs and FICRs exists. This correlation, however, is more prevalent among EICR2, FICR2 and FICR3, where FICR1 is poorly correlated with the other ICRs. The analysis carried out in the research showed that EICR2, FICR2 and FICR3 are preferable. EICR1 and FICR1, although very common in business practice and bank analysis, appear to overestimate the sustainability of the business cycle, providing superior results compared with the real data. They are also unrelated, as well as statistically different, if compared with the rest of the ICRs, which we believe are preferable (EICR2, FICR2, FICR3). The analysis also highlights the need for companies in the sector to prepare the financial statements in order to have data directly expressive of the financial sustainability of the business cycle. The preparation of financial statements is useful both for the purposes of internal analysis and for the improvement of dialogue with banks. This goal is particularly important in view of the general situation of financial crisis, such as the current economic situation, particularly in a sector characterized by the prevalence of SMEs.

The research, however, has some limitations; in fact, the analysis was conducted on a relatively small sample of firms. For this reason, it might be useful to deepen the research to a larger sample, also including cooperative enterprises. It should be noted, moreover, that in Italy, companies active as sole proprietorships or unincorporated partnerships are not required to file with 
the Register of Companies the annual budget and for this reason, they were not included in the sample. It would be useful to extend the analysis to these forms of firms, which are widely common in agriculture. Still, this research could be expanded to other countries, even in developing countries, in order to understand if the theme of the ICRs is important only in countries with mature economies or even in countries characterized by firms' difficulties in accessing credit, fragmentation of production in microenterprises and simplified production techniques. In addition, the research could be carried out considering a sample of dairy firms not producing milk to be transformed into cheese; in these companies, in fact, there may be less dilation of working capital cycle, with the consequence of a lower shift between the economic cycle and the financial cycle and, thus, less need to evaluate FICRs compared with traditional EICRs.

\section{ACKNOWLEDGEMENT}

The researchers would thanks analisiaziendale.it for IT assistance, particularly in the database management. The article is a result of the full collaboration of all the authors. However G. Bonazzi wrote paragraphs Introduction, Discussion, Conclusion while M. Iotti wrote paragraphs Materials and Methods, Results.

\section{RERERENCES}

Bahiraie, A., N.A. Bt Ibrahim and A.K.M. Azhar, 2009. On the predictability of risk box approach by genetic programming method for bankruptcy prediction. Am. J. Applied Sci., 6: 1748-57. DOI: 10.3844/ajassp.2009.1748.1757

Bonazzi, G. and M. Iotti, 2014. Agricultural cooperative firms: Budgetary adjustments and analysis of credit access applying scoring systems. Am. J. Applied Sci., 11: 1181-1192. DOI: 10.3844/ajassp.2014.1181.1192

Bonazzi, G., M. Iotti and F. Paduano, 2012. Valutazioni di convenienza e di sostenibilità per le imprese del comparto del Prosciutto di Parma Dop: Un'analisi attraverso l'applicazione di indici economici e finanziari. Rivista di Economia Agraria, 67: 61-98. DOI: 10.3280/REA2012-002003

Chaddad, F., M. Cook and T. Heckelei, 2005. Testing for the presence of financing constraints in US agricultural cooperatives: An investment behavior approach. J. Agric. Econom., 56: 385-397. DOI: 10.1111/j.1477-9552.2005.00027.x
Charitou, A. and G. Panagitodes, 1999. Financial analysis, future earnings and cash flows and the prediction of stock returns: Evidence for the UK. Account. Bus. Res., 29: 281-298. DOI: 10.1080/00014788.1999.9729589

Copeland, T., T. Koller and J. Murrin, 2000. Valuation: Measuring and Managing the Value of Companies. 3rd Edn., Wiley, New York, ISBN10: 0471361917, pp: 512.

Dechow, P.M. and I. Dichev, 2002. The quality of accruals and earnings, the role of accruals estimation errors. Account. Rev., 3: 35-59. DOI: 10.2308/accr.2002.77.s-1.35

Dechow, P.M., 1994. Accounting earnings and cash flow as measures of firm performance: The role of accounting accruals. J. Account. Econom., 18: 3-42. DOI: 10.1016/0165-4101(94)90016-7

Dichev, I. and D. Skinner, 2002. Large-sample evidence on the debt covenant hypothesis. J. Account. Res., 40: 1091-123. DOI: 10.1111/1475-679X.00083

Demerjian, P., 2011. Accounting standards and debt covenants: Has the "balance sheet approach" led to a decline in the use of balance sheet covenants? J. Account. Econom., 52: 101-158. DOI: 10.1016/j.jacceco.2011.08.004

Dothan, M., 2006. Costs of financial distress and interest coverage ratios. J. Financ. Res., 29: 147-162.

Dunn, P. and L. Cheatham, 1999. Fundamentals of small business financial management for start up, survival, growth and changing economic circumstances. Managerial Finance, 19: 1-13. Doi: 10.1108/eb013737

Finger, C.A., 1994. The ability of earnings to predict future earnings and cash flow. J. Account. Res., 32: 210-223.

Glancy, K., 1998. Determinants of growth and profitability in small entrepreneurial firms. Int. J. Enterpreneurial Behav. Res., 4: 18-27.

Goldstein, R., N. Ju and H. leland, 2001. An EBITbased model of dynamic capital structure. J. Bus., 74: 483-512. DOI: 10.1086/322893

Grablowsky, B.J., 1984. Financial management of inventory. J. Small Bus. Manag.

Gray, S., A. Mirkovic and V. Ragunathan, 2006. The determinants of credit ratings: Australian evidence. Aus. J. Manage., 31: 333-54. DOI: 10.1177/031289620603100208

Grenberg, R.R., G.L. Johnson and K. Ramesh, 1986. Earnings versus cash flow as a predictor of future cash flow measures. J. Account., 1: 266-277. DOI: 10.1177/0148558X8600100402 
Healy, P.M., 1985. The effect of bonus scheme on accounting decisions. J. Account. Econom., 7: 85107. DOI: $10.1016 / 0165-4101(85) 90029-1$

Hussain, S. and A. Al-Attar, 2003. Corporate data and future cash flows. J. Bus. Finance Account., 31: 861-903. DOI: 10.1111/j.0306-686X.2004.00560.X

Iotti, M. and G. Bonazzi, 2012. EBITDA/EBIT and cash flow based ICRs: A comparative approach in the agro-food system in Italy. Financial Asset Invest., 2: 19-31. DOI: 10.5817/FAI2012-2-2

Iotti, M. and G. Bonazzi, 2014b. Comparative analysis of return on equity and cash flow generation in the Parma PDO ham sector. J. Applied Sci., 14: 2460-2475. DOI: 10.3923/jas.2014.2460.2475

Iotti, M. and G. Bonazzi, 2014a. The application of Life Cycle Cost (LCC) approach to quality food production: A comparative analysis in the Parma PDO ham sector. Am. J. Applied Sci., 11: 14921506. DOI: 10.3844/ajassp.2014.1492.1506

Iotti, M. and G. Bonazzi, 2014c. Tomato processing firms' management: A comparative application of economic and financial analyses. Am. J. Applied Sci., 11: 1135-1151. DOI: 10.3844/ajassp.2014.1135.1151

Kieschnick, R., M. LaPlante and R. Mousawwi, 2008. Working capital management, corporate governance and firm value. University of North Texas University Press, Austin.

Krishnan, G.V. and L. Largay, 2000. The predictive ability for direct method cash flow information. J. Bus. Finance Account., 12: 215-245. DOI: 10.1111/1468-5957.00311

Krolick, D.L., 1998. The relevance of financial statement information for executive performance evaluation and equity valuation: Evidence from choice of bonus plan accounting performance measures. PhD., Thesis, University of Chicago.

Kwon, Y.K., 1989. Accrual versus cash-basis accounting method: An agency-theoretic comparison. J. Account. Public Policy, 8: 267-281. DOI: 10.1016/0278-4254(89)90015-X

Limsombunchai, V., C. Gan and M. Lee, 2005. An analysis of credit scoring for agricultural loans in Thailand. Am. J. Applied Sci., 2: 1198-1205. DOI: 10.3844/ajassp.2005.1198.1205

Molina, C.A. and L.A. Preeve, 2009. Trade receivables policy of distressed firms and its effect on the costs of financial distress. Financ. Manage., 38: 663-86.
Peel, M.J. and N. Wilson, 1996. Working capital and financial management practices in the small firm sector. Int. Small Bus. J., 14: 52-68. DOI: 10.1177/0266242696142004

Penman, S., 2004. Financial Statement Analysis and Security Valuation. 1st Edn., McGraw-Hill, London.

Richardson, S.A., 2005. Accrual reliability, earnings persistence and stock prices. J. Account. Econom., 39: 437-485. DOI: 10.1016/j.jacceco.2005.04.005

Russel, P.B., 2009. The cash flow implication of managing working capital and capital investment. J. Bus. Econom. Studies, 15: 98-108.

Sgroi, F., A.M. Di Trapani, R. Testa and S. Tudisca, 2014. Strategy to increase the farm competitiveness. Am. J. Agric. Biol. Sci., 9: 394-400. DOI: 10.3844/ajabssp.2014.394.400

Sloan, R., 1996. Do stock prices fully reflect information in accruals and cash flows about future earnings? Account. Rev., 71: 289-315.

Trejo-Pech, C.O., R. Weldon, L. House and T. SalasGutierrez, 2006. Accruals, free cash flow and EBITDA for agribusiness firms. Proceedings of the American Agricultural Economics Association Annual Meeting, Jul. 23-26, Long Beach, California, pp: 301-319.

Tudisca, S., A.M. Di Trapani, F. Sgroi and R. Testa, 2013. The cost advantage of Sicilian wine farms. Am. J. Applied Sci., 10: 1529-1536. DOI: 10.3844/ajassp.2013.1529.1536

Tudisca, S., A.M. Di Trapani, F. Sgroi and R. Testa, 2014a. Economic evaluation of PDO introduction in Sicilian orange farms. Quality-Access Success, 14: 99-103.

Tudisca, S., A.M. Di Trapani, F. Sgroi and R. Testa, 2014b. Organic farming and economic sustainability: The case of Sicilian durum wheat. Quality-Access Success, 15: 93-96.

Wallace, R.S.O., M.S.I. Choudhury and M. Pendlebury, 1997. Cash flow statement: An international comparison of regulatory position. Int. J. Account., 22: 1-22. DOI: 10.1016/S0020-7063(97)90002-9

Wang, Z. and J. Eichenseher, 1998. Informativeness and predictability of cash flows. J. Applied Bus. Res., 14: 21-32. 